\title{
Management of the common property of an apartment building: legal issues
}

\author{
Ulyana Filatova ${ }^{1}$, Natalia Dalbaeva ${ }^{1}$, Nina Semeryanova ${ }^{2}$, Ludmila Dolnikova ${ }^{2}$, Dmitriy \\ Bayanov $^{3, *}$ \\ ${ }^{1}$ Irkutsk State University, Law Institute, Ulan-Batorskaya str., 10, Irkutsk, 664082, Russia \\ ${ }^{2}$ South Ural State University (National Research University), Nizhnevartovsk Branch, Mira str., 9, \\ 628600, Russia \\ ${ }^{3}$ Tyumen Industrial University, Volodarskogo str., 38, Tyumen, 625000, Russia
}

\begin{abstract}
The article discusses the main issues of the legal regime of public facilities in non-residential buildings, the system of management of such property. The relevance of the research topic is manifested in the following aspects. With the development of market economy, the need to use non-residential premises, including those located in buildings, has increased. The presence of material base is an essential condition for the development of entrepreneurial activity. However, legislative gaps in the field of common property management by owners of non-residential premises lead to deceleration of economic processes and adversely affect sustainable development and welfare of cities. For a long time, in theory and practice, there were different opinions about the possibility of extending, by analogy with the common property of the building, provisions on the common property regime of an apartment building. Despite the fact that the issue of legal vacuum was partially solved by the Supreme Arbitration Court of the Russian Federation by the issuance of Resolution No. 64 of the Plenum of July 23, 2009, many questions on the legality of using the proclaimed analogy of the law still do not find an unequivocal solution in lawmaking and law enforcement activities of relevant legislative and judicial bodies.
\end{abstract}

\section{Introduction}

In legal literature, the subject of apartment buildings management is in demand. Among the authors who pay attention to the apartment buildings management, I would like to mention: D.P. Gordeeva, N.A. Dolgov, I.A. Drozdova, O.E. Zhuliev, I.V. Markov, S.G. Pevnitsky, A.V. Popova, V.D. Ruzanova, A.B. Ryzhov, D.B. Solovyov, U.B. Filatov, E.A. Chefranovu, S.Yu. Shakhova, T.O. Yakubov et al.

For example, S.G. Pevnitsky [1], U.B. Filatov [2] investigated the peculiarities of legal relations of ownership of common property in an apartment building; A.V. Popov [3], T.O. Yakubov [4] analyzed the individual methods of managing an apartment building; O.N. Dolgov [5], O.E. Zhulieva [6], considered the peculiarities of contract for the management

*Corresponding author: a.copytowa@yandex.ru 
of an apartment building. However, a detailed analysis that reveals the complex nature of the legal regulation of the apartment buildings management, including non-residential premises, is not enough in the literature. The legal regulation of relations on non-residential premises and buildings is currently carried out by civil and housing legislation. In the Housing Code of the Russian Federation, the features of non-residential premises located in apartment buildings are taken into account to a certain extent, the mode of common ownership of non-residential premises related to common property is disclosed, uniform rules are developed for owners of residential and non-residential premises, defining the procedure for common property management in an apartment building. However, the legislation does not formulate clear criteria for assigning non-residential premises to this property. These circumstances have led to the formation of controversial jurisprudence on the determination of legal status of basement non-residential premises in apartment buildings, auxiliary non-residential premises in buildings, and management of common property. The proposal to apply the analogy of the law contained in the Resolution of the Plenum of the Supreme Arbitration Court of the Russian Federation No. 64 dated July 23, 2009 "On some issues of the practice of disputes regarding the rights of owners of premises to the common property of a building" (hereinafter referred to as the Resolution of the Supreme Arbitration Court dated July 23, 2009 . № 64), is debatable.

The purpose of the work is to identify peculiarities of the right of common ownership of common property in buildings, implementation of common property management activities, and formulation of proposals for improving legislation that will streamline relations that are developing in this area.

Achieving the goal is possible due to following research tasks:

- to conduct comparative analysis of relations arising between the owners of the premises in the apartment building and non-residential building;

- to study the features of legal regime of non-residential premises located in buildings, depending on their types;

- to formulate the concept of managing the owners of common property in non-residential buildings.

The scientific novelty of the research lies in the formulation, justification and solution of problems of managing common property by owners of non-residential premises in a building.

\section{Methods}

The work is based on the methodological tools traditionally used in jurisprudence. The philosophical basis was made by the dialectic method that allowed revealing the institution of management of apartment buildings, given the contradictions in its development. The formal legal method made it possible to establish the legal content of the legal regulation of relations in the management of apartment buildings by interpreting the norms of current legislation. The application of the method of comparative analysis by comparing one-order legal phenomena, such as the composition of the common property of an apartment building and non-residential building, provided clarification of differences between them, which in turn has an impact on the realization of the right of common ownership of common property.

The empirical basis of the work consisted of existing civil and housing legislation, as well as the prevailing judicial practice. General provisions on the composition of the common property of an apartment building are disclosed in the Housing Code of the Russian Federation; for non-residential objects, explanations are given in the resolution of the Plenum of the Supreme Arbitration Court of the Russian Federation. The Land Code of the Russian Federation establishes the rights of the owner of the premises in non-residential 
buildings to acquire a land plot under the building into common shared ownership, or to obtain the right to use the relevant lot on the basis of a lease agreement. The paper uses the statistics of the Fund for Assistance to the Housing and Utilities Reform in the Irkutsk Region.

Review of research literature. The issues considered in this article, in particular those related to the legal essence of management of an apartment building and definition of the concept of this phenomenon, were studied in the works of T. A. Coast, D. P. Gordeeva, I. V. Markova, V. D. Ruzanova, I. V. Rekhtina and others. O. A. Oleynikova, Yu. P. Sweet, S.L. Tyurin have studied acquisition, realization and termination of the right of common ownership of the common property by the owners of non-residential premises in apartment buildings, including buildings and the need to improve the legal regulation of this area of housing relations.

\section{Results}

The owner of a separate room in the building owns a share in the right of common ownership of the common property of the building. Since the common property of an apartment building is a specific set of objects, its composition must be determined in each specific case. General provisions on the composition of the common property of an apartment building are contained in paragraph 1 of Art. 36 LCD RF. By analogy, these provisions apply to non-residential buildings (Section 1 of the Resolution of the Plenum of the Supreme Arbitration Court of the Russian Federation No. 64 dated July 23, 2009).

The common property includes, in particular, premises intended for servicing more than one premise in an apartment buildingt.

The composition of the common property of an apartment building includes the land where the house is located, with elements of gardening and landscaping. It should be noted that the conditions for provision and use of land plots under apartment buildings and other buildings, where the premises are owned by several persons, have significant differences. Firstly, relations on the acquisition of a land plot under a non-residential building are regulated by civil and land legislation. Secondly, for the owners of non-residential buildings there is no mechanism for automatic gratuitous acquisition of property rights after formation of relevant land plot, as provided for by Art. 16 of the Federal Law of the Russian Federation "On the introduction of the Housing Code of the Russian Federation". Thirdly, owners of premises in non-residential buildings can acquire land under the building not only for common shared ownership, but also receive the right to use the relevant plot on the basis of a lease agreement with a plurality of persons on the tenant's side (Article 39.20 of the Land Code of the Russian Federation). Application of provisions of Art. 36 Housing Code of the Russian Federation by analogy to determining the composition of the common property of a non-residential building is not always possible without reservations.

The issue of limits of disposal of individual objects belonging to the common property of an apartment building is among the discussion. First of all, it concerns such common property objects as basements, attics and other technical premises, which in practice are often isolated as independent real estate objects and transferred for use, as a rule, under lease agreements. It is believed that even with the possibility of conversion of attics and basements into non-residential premises, they still should not be considered as independent real estate.

The second position is based on the delimitation of premises included in the common property, on having exclusively technical purpose and possessing other, besides technical, useful properties. This approach is widely used in court practice. For example, in a dispute reviewed by the FAC, the homeowners disputed the state registration of non-residential 
premises (basement) for a limited liability company. The case was sent for new considerations in order to find out whether there are really engineering communications in the disputed premises, designed to serve the whole house. This circumstance is recognized as decisive, but not the validity of the title documents, on which basis the state registration of property rights was made, or the procedure for financing the construction of these premises. At the same time just to make sure the availability of engineering communications in the basement is not enough. In the case, according to the results of the review, it became clear that the disputed premises do not belong to the technical ones in the sense of the Civil Code of the Russian Federation [12]. They really are the pipes for heating, hot and cold water supply and sewage, but they are not equipped with shut-off and control valves, they do not have mechanical, electrical, sanitary and other equipment serving more than one room, and therefore they cannot be recognized common areas. Such premises have an independent cadastral number and are part of the non-residential fund, i.e. formed as independent real estate. Thus, with regard to the possibility of separating individual objects of common property of an apartment building and setting limits for their use in civil circulation, neither a single law nor a court practice has formed a unified approach. However, the need for gradation of common property with the possible establishment of features of the mode of relatively autonomous objects is not in doubt. The introduction of ban on the turnover of these objects can hardly be considered justified..

Housing Code of the Russian Federation allows management of apartment buildings in the following ways: direct management of the owners of the premises in the apartment building, when the number of apartments is not more than thirty; management of the HOA or $\mathrm{HBC}$ or other specialized consumer cooperatives; management of the managing organization.

According to statistics for 2015, in the Russian Federation HOA, housing cooperatives manage 113164 apartment buildings. In ten years from the date of entry into force of the Housing Code of the Russian Federation, the number of apartment buildings operated by the HOA increased slightly more than 2 times. In the Irkutsk Region, 15,110 apartment buildings are under the control of 493 management organizations, including 231 Homeowners. There is also information about 212 management organizations currently not managing homes.

In accordance with clause 5 of Resolution No. 64 of the Supreme Court of Arbitration of the Russian Federation of July 23, 2009, by decision of the owners of the premises, adopted in accordance with the procedures provided for in Articles $44-48$ of the Housing Code of the Russian Federation, the use of the common property of the building, in particular individual common premises, can be established. On the one hand, the cost of maintaining common property is inextricably linked with the possession and use of common property, therefore, according to Art. 247 of the Civil Code of the Russian Federation decision-making on the determination of the procedure for carrying them must be carried out by all owners. On the other hand, the Supreme Court of Arbitration of the Russian Federation indicates: the owners are entitled to determine such an order by a majority of votes in accordance with the procedure established by the Housing Code.

Judicial practice justifying the possibility of applying to such relations the provisions of the Housing Code, is based on the similarity of relations.

However, there is another approach developed by the law enforcer. Thus, in one of the cases, the Arbitral Court concluded that the decision to bear the costs associated with the maintenance of common property, in the absence of $100 \%$ attendance of all owners, does not comply with Art. 247 of the Civil Code, therefore, is legally void.

It should be noted that, depending on the legal justification of the judicial position, the procedure for the owners to bear the costs of maintaining common property is determined. 
Housing and communal services statistics show that the fall in household incomes led to an increase in debt to the housing and utilities sector. In 2017, the amount reached 1.34 trillion. rub. Of these, about 650 billion rubles make debts of the population. The rest of the debt lies primarily with the MA. Table 1 presents comparative data on the established level of payment for housing and public utilities by constituent entities of the Russian Federation and actual level of payment (1st quarter of 2017).

Table 1 - Data on the established level of payment for housing and public utilities in the regions of the Russian Federation

\begin{tabular}{|l|c|c|c|c|}
\hline \multicolumn{1}{|c|}{ Regions } & $\begin{array}{c}\text { The established } \\
\text { level of payments } \\
\text { for the maintenance } \\
\text { of housing (\%) }\end{array}$ & $\begin{array}{c}\text { Cost } \\
\text { recovery } \\
\text { rates (\%) }\end{array}$ & $\begin{array}{c}\text { The established } \\
\text { level of } \\
\text { payments for } \\
\text { utilities (\%) }\end{array}$ & $\begin{array}{c}\text { Cost } \\
\text { recovery } \\
\text { rates (\%) }\end{array}$ \\
\hline RF & 99.5 & 88.9 & 82.7 & 82.9 \\
\hline Central FD & 99.0 & 91.1 & 99.0 & 86.5 \\
\hline $\begin{array}{l}\text { North-Western } \\
\text { FD }\end{array}$ & 99.9 & 87.6 & 92.5 & 86.8 \\
\hline Southern FD & 100.0 & 83.5 & 97.4 & 92.2 \\
\hline $\begin{array}{l}\text { North Caucasus } \\
\text { FD }\end{array}$ & 100.0 & 76.1 & 99.1 & 70.0 \\
\hline Volga FD & 99.9 & 90.4 & 92.9 & 87.4 \\
\hline Ural FD & 99.7 & 87.5 & 93.0 & 83.1 \\
\hline Siberian FD & 99.5 & 88.5 & 91.5 & 80.3 \\
\hline Far Eastern FD & 99.6 & 85.4 & 62.2 & 54.2 \\
\hline
\end{tabular}

In other words, when applying the norms of the Housing Code of the Russian Federation to the relations of the parties, the cost of the owner for the maintenance of common property is calculated according to the tariffs approved at the general meeting, since on the basis of clause 5 of Art. 46 Housing Code of the Russian Federation General Assembly decision is mandatory for all owners, including those who did not participate in the voting. If the disputed relationship between the owner and the managing organization is regulated by the Civil Code of the Russian Federation, then the owner's costs for common property are determined in accordance with the rules on unjust enrichment. According to the statistics of the AIS "Judicial Proceedings" for the period from January 1, 2015 to November 24, 2015, the Arbitration Court of the East-Siberian District considered 277 disputes related to the application of legislation on energy supply, the provision of public services (6.6\% of the total cases), in 2017 the number of such cases has increased to 539 .

The analysis and synthesis of court practice (resolution of the Presidium of the Supreme Court of Arbitration of the Russian Federation of September 10, 2002 N 3673/02; resolution of the Arbitration Court of the Ural District of November 30, 2014 in case No. A71-603 / 2014; decision of the Moscow Arbitration Court of 30 December 2014, case No. A40-174366 / 13; decision of the Ninth Arbitration Court of Appeal of September 6, 2012, No. A40-9158 / 12-102-8; decision of the Arbitration Court of the Sverdlovsk Region of May 12, 2010 No. A60 -57683; appeal definition of the Krasnodar Regional Court of September 9, 2014 in case N 33-19636; appeal determination of Voronezh Regional Court of November 25, 2014 in case N 33-6064; definition of the Moscow City Court of April 3, $2015 \mathrm{~N} \mathrm{4g}$ / 8-1540 and others allowed to speak about the high degree of relevance of this category of disputes.

\section{Discussion}


In theory, there is still no unambiguous idea of what management of an apartment building is and what the volume of management activity is. By fair statement of V.D. Ruzanova, the reason for this is confusion of the concepts of "managing an apartment building as a management method" and "realizing the powers of the owner". The analysis of legislative acts allows us to conclude that management covers not only direct work, but also forecasting, planning relevant activities, making decisions, and monitoring their implementation. Given this circumstance, the doctrine of the content management of an apartment building is considered in a broad sense, with the release within the various levels (subsystems). It is quite obvious that the basis for the management system of an apartment building is self-government, which is carried out by the owners of the premises of the apartment building using general meetings. The results of this study can be used in further scientific research in the field of common property management in apartment buildings on improving quality of housing and public services and sustainable development of Russian cities.

\section{Conclusion}

Thus, analysis of current legislation and judicial practice shows that legal regulation of common property regime of a non-residential building, despite its significant similarity to common property regime of an apartment building, should be carried out by special rules. Application of analogy of the law does not always ensure interests of owners of the premises of building. Considering different purpose of non-residential premises, more flexible rules should be established regarding determination of composition of common property and possibilities for specific owners to use this property. The general meeting of owners of premises in an apartment building as a decision-making mechanism is not always the most effective tool for managing co-owners of common property. In this regard, it is necessary to further improve decision-making procedures of the general meeting, reduce the quorum of the general meeting and the number of votes necessary for making decisions, regulate the procedures for the representation of common property co-owners. Creating a favorable legislative procedure for attracting citizens to participate in resolving issues of common property management, increasing the activity of owners is one of the ways to influence the choice of service and resource supplying organizations that provide utilities and carry out maintenance work on common property.

It can be concluded that the professional management of common property in apartment buildings will contribute to improving the quality of housing and public services and the sustainable development of Russian cities.

\section{References}

1. S. G. Pevnitsky, Management of apartment houses with the help of specialized legal entities, Law. 6, p. 37-40 (2007)

2. U. B. Filatov, The common property of the owners of the premises in an apartment building, p. 26 (Irkutsk, 2006)

3. A. V. Popov, The partnership of homeowners as a legal form that mediates the powers of the owners of the premises in an apartment building, p. 22 (Volgograd, 2006)

4. T. O. Yakubova, Legal regulation of relations in the management of apartment buildings, p. 25 (Moscow, 2013) 
5. O. E. Zhulyeva, Contractual relations in the management of an apartment building in accordance with the civil legislation of the Russian Federation, p. 22 (Volgograd, 2007)

6. Yu. P. Sweet, Features of the ownership of the common property of apartment buildings and non-residential buildings, Laws of Russia: experience, analysis and practice, 6, p. 38-47 (2011)

7. O. A. Oleynikova, Problems of regulation of relations arising between owners of premises in a non-residential building regarding common property, Lawyer, 15, p. 23 26 (2016)

8. O. V. Kirichenko, Real Estate Ownership Partnership (TSN) as an effective way to manage apartment buildings, Family and housing law, 4, p. 26-30 (2015)

9. D. P. Gordeev, Changing the legal status of homeowners' associations as an association of owners of residential and non-residential premises in an apartment building, Consultant Plus.

10. V. A.Belov, S. A. Bushaenkova, Civil law relations in the management of an apartment building, Legislation, 12, p. 23-31 (2006)

11. T. A. Beregovaya, Topical issues of private law and public law regulation of the management of apartment buildings, Laws of Russia: experience, analysis, practice, $\mathbf{1}$, p. 12-16 (2017)

12. V. D. Ruzanova, Problems of realization of the powers of the owners of the premises in an apartment building as members of the HOA, Problems of the legal status of participants in legal entities: Collection of scientific articles, p. 122 (Samara, Universgroups, 2008)

13. A. Minnullina, Expert assessment of the current state of the energy management system in the company. IOP Conference Series: Earth and Environmental Science 90, pp. 012089 (2017) doi:10.1088/1755-1315/90/1/012089

14. N. Zotkina, A. Kopytova, M. Zenkina, O. Zhigunova, MATEC Web of Conferences, 106, 08058 (2017) DOI: 10.1051/matecconf/201710608058

15. On the procedure for the management of apartment buildings: Decree of the Government of the Russian Federation of May 15, 2013 (as amended on 13.09.2018), 416 Collection of the Legislation of the Russian Federation, 21, Art. 2652 (2013)

16. A. Kopytova, Procedia Engineering 165, 1132 (2016) DOI: 10.1016/j.proeng.2016.11.830

17. I. V. Rekhtina, Management of an apartment house: legal and economic aspects, Family and housing law, 5, p. 45 -47 (2011)

18. I. V. Markova, Legal problems of common property management in an apartment building, Russian legal journal, 1, p. 111 - 119 (2008)

19. A. Kopytova, MATEC Web of Conferences, 106, 08056 (2017) DOI: 10.1051/matecconf/201710608056

20. V. Lezier, M. Gusarova, A. Kopytova, IOP Conference Series: Earth and Environmental Science, 90(1), 012069 (2017) DOI: 10.1088/1755-1315/90/1/012069

21. N. Zotkina, M. Gusarova, A. Kopytova, Advances in Intelligent Systems and Computing 692, 1204-1213 (2018) DOI: 10.1007/978-3-319-70987-1_129

22. A. Minnullina, A. Mottaeva, Formation of the priority directions of innovative strategic energy management. IOP Conference Series: Earth and Environmental Science, 90, pp. 012123 (2017) doi:10.1088/1755-1315/90/1/012123 
